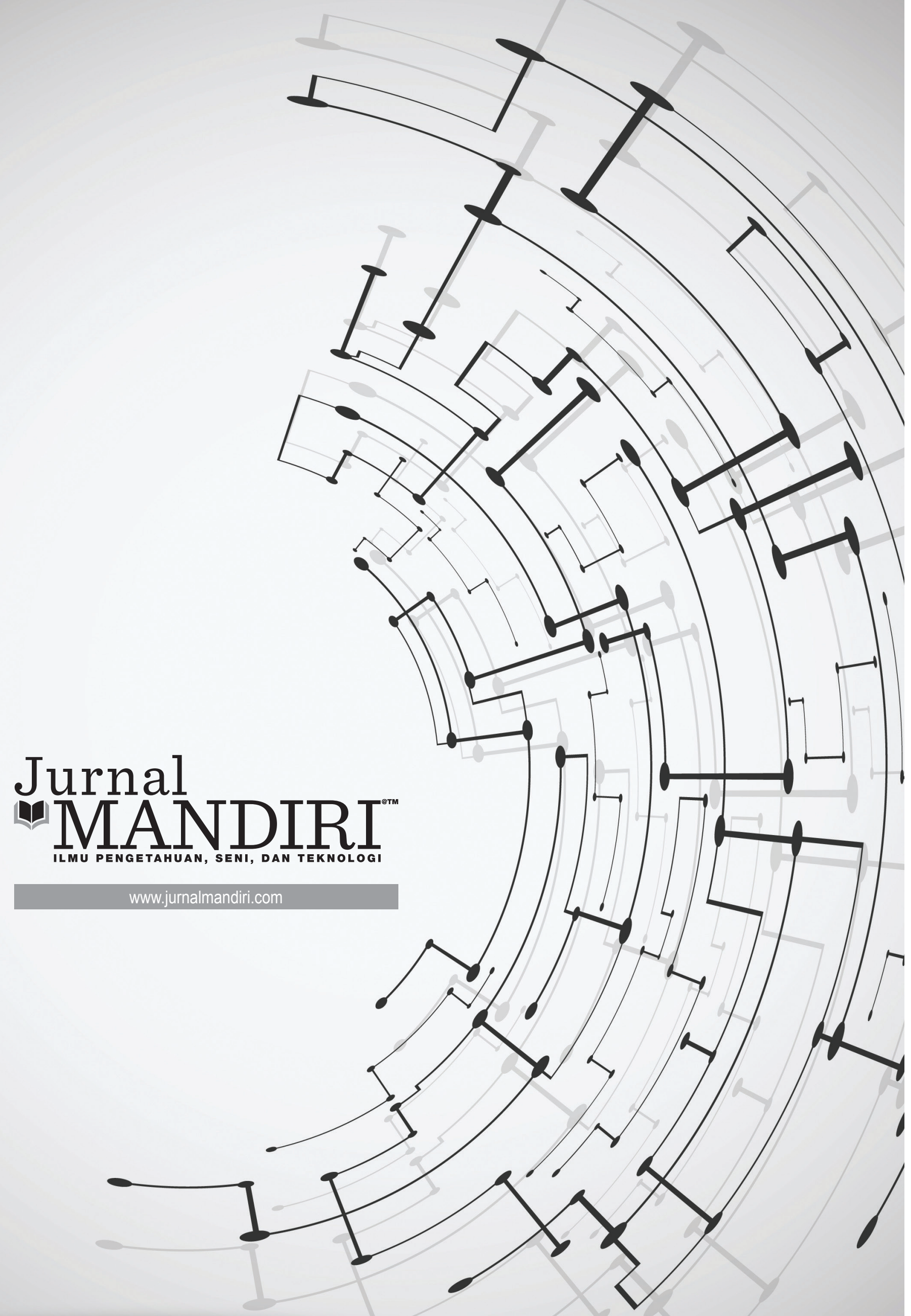


ISSN : 2580-3220, E-ISSN : 2580-4588

J. Mandiri., Vol. 1, No. 2, Desember 2017 (312 - 328)

(C2017 Lembaga Kajian Demokrasi

dan Pemberdayaan Masyarakat (LKD-PM)

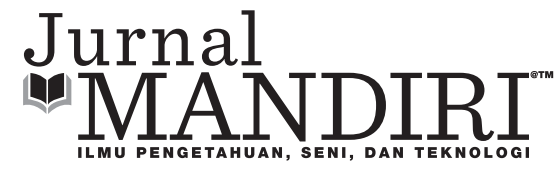

\title{
STRATEGI PEMASARAN PARIWISATA INDONESIA SEBAGAI ANTISIPASI DARI PERUBAHAN EKONOMI GLOBAL
}

\author{
Jaenudin \\ Universitas Pamulang \\ zaenuddin_t@yahoo.com
}

\begin{abstract}
ABSTRAK
Adanya faktor-faktor dari sektor pariwisata yang dapat mempengaruhi pertumbuhan ekonomi. Strategi-strategi yang digunakan untuk meningkatkan industri pariwisata adalah dengan strategi matrik pertumbuhan pangsa pasar, matrik portofolio multifaktor ADL, product life cycle. Dengan strategistrategi tersebut diharapkan akan meningkatkan pemasukan di sektor industri dan akan mempengaruhi pertumbuhan ekonomi. Dalam penelitian ini penulis menggunakan analisis deskriptif, kualitatif dan trend. Hasil dari penelitian ini adalah Indonesia memiliki potensi yang sangat besar namun tidak diimbangi dengan sumber daya manusia yang baik analisis industri yang baik sehingga kalah bersaing dengan negara lain.
\end{abstract}

Keyword : Strategi matrik pertumbuhan pangsa pasar, matrik portofolio multifaktor ADL, product life cycle, sektor pariwisata, pertumbuhan ekonomi, Strategi Bersaing, GDP.

\section{PENDAHULUAN}

\section{Latar Belakang}

Mengingat pariwisata diharapkan menjadi penyangga pertumbuhan ekonomi di masa depan, maka ia harus dipandang sebagai proses berkesinambungan dari waktu ke waktu. Pandangan semacam ini akan mendorong kepada langkah-langkah penuh antisipatip. Langkah antisipasi harus didasarkan kepada ketajaman kemampuan memprediksi yang didukung dengan data-data hasil penelitian secara cermat.

Berdasarkan pengamatan beberapa analisa pariwisata yang dilakukan oleh lembaga studi pariwisata nasional maupun internasional, ditemukan ciri ciri dan kecenderungan pariwisata memasuki tahun 2000 lebih sebagai berikut:

a. Pariwisata akan identik dengan pusat pertumbuhan ekonomi;

b. Permintaan akan melebihi penawaran;

c. Kompetisi akan bersifat global, dimana perusahaan multinasional di bidang jasa pariwisata dan aliansinya akan mendominasi pasar pariwisata dan biro perjalanan;

d. Dampak lingkungan dan sosial budaya dari peristiwa akan menjadi isu yang penting;

e. Struktur jasa pariwisata dan biro perjalanan akan mengalami perubahan karena dipakainya teknologi modern, sistem moneter internasional dan lain lain. 


\section{RUMUSAN MASALAH}

Rumusan masalah dalam penelitian ini adalah sebagai berikut:

1. Ketika sektor pariwisata diproyeksikan sebagai andalan dalam memacu pertumbuhan ekonomi Indonesia, secara operasional sering diharapkan kepada kendala-kendala yang tidak ringan untuk mengatasinya, terutama berkaitan dengan strategi pengembangan yang dapat dijadikan pola kebijaksanaan pemerintah. Adakah peluang untuk mencapainya?

2. Jika prospek peluang pangsa pasarnya cerah, strategi bisnis apa dan bagaimana pula hal itu dapat diformulasikan dalam upaya menjawab tantangan manajemen kepariwisataan Indonesia?

3. Sektor pariwisata pada pembangunan Jangka Panjang II menjadi andalan perolehan devisa melalui masuknya wisatawan mancanegara, dalam kaitan keadaan perekonomian Indonesia adakah Wisatawan Nusantara (Wisnus) mempengaruhinya?

4. Sebagai negara berkembang, mungkinkah kepariwisataan Indonesia mampu menerobos dalam ketatnya persaingan di antara sesama negara ASEAN dalam menyedot arus wisatawan mancanegara?

\section{PEMBATASAN MASALAH}

\section{Tujuan Penelitian}

Tujuan penelitian adalah sebagai berikut:

1. Untuk mengetahui peluang pasar pariwisata Indonesia di tengah gencarnya sosialisasi terutama oleh pemerinta, sebagai sektor industri yang merupakan andalan perolehan deisa negara.

2. Untuk mengetahui strategi bisnis apa dan bagaimana hal itu dapat diformulasikan sebagai langkah yang dapat ditempuh dalam upaya menjawab tantangan manajemen pariwisata Indonesia di tengah ketatnya persaingan bisnis.

3. Untuk dapat menemukan analisis-analisis yang secara proporsional dapat menunjuk- kan kendala-kendala yang dihadapidan dipandang sebagai penghambat pertumbuhan dan pengembangan sektor pariwisata sebagai usaha di bidang industri jasa.

4. Untuk dapat menemukan rumusan-rumusan sebagai terobosan di tengah ketatnya persaingan yang semakin mengglobal, termasuk kemungkinan perlunya daya saing pariwisata Indonesia ditingkatkan, baik itu menyangkut prasarana dan sarana fisik maupun kemampuan sumberdaya insani.

\section{Tinjauan Teoritik}

Istilah pariwisata sebagai suatu konsep, berkaitan dengan keindahan alam, keragaman budaya, dan perjalanan manusia dari suatu tempat ke tempat yang lain dengan melibatkan perangkat (transportasi dan akomodasi dari tingkat sederhana hingga tingkat mewah) secara sukarela. Tiga hal pokok yang berkaitan dengan pemasaran di industri pariwisata. Pertama, aspek yang dikunjungi yaitu destinasi wisata atau Daerah Tujuan Wisata (DTW) dengan berbagai variasinya. Kedua, aspek prasarana dan sarana yang harus disediakan atau diusahakan untuk ada oleh pihak industri jasa. Ketiga, aspek pengunjung, dimana mereka merupakan tamu yang diharapkan kedatangannya (Wisatawan Mancanegara/Wisman dan Wisatawan Nusantara/Wisnus).

Menurut Michael E. Porter (Strategi Bersaing, terjemahan Agus Maulana,1996) bahwa dalam menanggulangi kekuatan persaingan, ada tiga pendekatan strategi generik yang secara potensial akan berhasil untuk mengungguli perusahaan lain dalam suatu industri: Pertama, Keunggulan biaya menyeluruh; Kedua, differensiasi; Ketiga, fokus.

Keterkaitan pariwisata dengan pembangunan ekonomi memiliki tiga unsur atau kunci meliputi:

(1) jenis pariwisata;

(2) struktur ekonomi nasional;

(3) hubungan antara perpindahan modal dan dan migrasi tenaga kerja. 
Peranan pariwisata dalam pembangunan nasional tergantung secara parsial pada organisasi modal dan khususnya kemampuan modal dari luar negeri untuk masuk ke dalam negeri mengingat pembangunan dan pengembangan pariwisata membutuhkan investasi yang tidak sedikit. Dengan begitu, keterlibatan berbagai fihak baik pemerintah, swasta, dan masyarakat dipandang sebagai suatu keharusan dimana perekonomian diukur dari produk domestik bruto (GDP).

Dalam menganalisis struktur industri pariwisata dan peranannya dalam pembangunan ekonomi dapat menjadi positif dan negatif. Hal ini bergantung pada kriteria yang dipakai ( misalnya pertumbuhan ekonomi melawan pemerataan pendapatan), sifat dari industri sendiri, dan sifat perekonomian lokal.

Matriks pertumbuhan Pangsa Pasar terdiri atas star, cash cow, question mark, dan dog. Star adalah matriks yang memiliki pangsa pasar tinggi dan pertumbuhan pasar tinggi. Cash cow adalah matrks yang memiliki pangsa pasar tinggi namun pertumbuhan pasar rendah. Question mark adalah mariks yang memiliki pertumbuhan pasar yang tinggi namun pangsa pasar rendah. Dog adalah pertumbuhan pasar rendah dan pangsa pasar rendah.

\begin{tabular}{c|c|c|c}
\multicolumn{2}{c}{ Pangsa Pasar } \\
\cline { 2 - 3 } Tinggi & Star & Question Mark & \multirow{2}{*}{$\begin{array}{c}\text { Pertumbuhan } \\
\text { Rendah }\end{array}$} \\
\cline { 2 - 3 } & Cash Cow & Dog & Rasar \\
\cline { 2 - 3 } & Tinggi & Rendah &
\end{tabular}

Matrik Portofolio Multifaktor ADL terdiri atas sembilan kotak matriks secara vertikal kekuatan dan bisnis perusahaan, dan horizontal daya tarik industri. Kotak 1 adalah daya tarik industri tinggi dan kekuatan bisnis perusahaan yang tinggi. Kotak 2 adalah daya tarik industri menengah dan kekuatan bisnis perusahaan tinggi. Kotak 3 adalah daya tarik industri rendah dan kekuatan bisnis perusahaan tinggi. Kotak 4 adalah daya tarik industri tinggi dan kekuatan bisnis perusahaan sedang. Kotak 5 adalah daya tarik industri sedang dan kekuatan bisnis perusahaan sedang. Kotak 6 daya tarik indus- tri rendah dan kekuatan bisnis sedang. Kotak 7 adalah daya tarik industri tinggi dan kekuatan bisnis perusahaan rendah. Kotak 8 adalah daya tarik industri sedang dan kekuatan bisnis perusahaan rendah.

\begin{tabular}{|c|c|c|c|c|}
\hline \multirow{4}{*}{$\begin{array}{c}\text { Kekuatan Bisnis } \\
\text { Perusahaan }\end{array}$} & \multicolumn{3}{|c|}{ Daya Tarik Industri } & \multirow{4}{*}{$\begin{array}{l}\text { Tinggi } \\
\text { Sedang } \\
\text { Rendah }\end{array}$} \\
\hline & 1 & 2 & 3 & \\
\hline & 4 & 5 & 6 & \\
\hline & 7 & 8 & 9 & \\
\hline & Ting & ed & end & \\
\hline
\end{tabular}

Sumber : Irawan dan Faried Wijaya, 1996, Pemasaran dan kasus, edisi 2

Product Life Cycle terdiri atas 20 kotak matriks dimana horizontal merupakan daur hidup produk dan vertikal merupakan posisi persaingan.

\begin{tabular}{|c|c|c|c|c|c|}
\hline \multirow{2}{*}{ Posisi Persaingan } & \multicolumn{4}{|c|}{ Daur Hidup Produk } & \multirow{3}{*}{$\begin{array}{l}\text { Dominan } \\
\text { Kuat }\end{array}$} \\
\hline \multirow{5}{*}{ Posisi Persaingan } & 1 & 2 & 3 & 4 & \\
\hline & 5 & 6 & 7 & 8 & \\
\hline & 9 & 10 & 11 & 12 & Baik \\
\hline & 13 & 14 & 15 & 16 & Sedang \\
\hline & 17 & 18 & 19 & 20 & Lemah \\
\hline & 1 & G & $M$ & D & \\
\hline
\end{tabular}

Sumber: Data Diolah

Keterangan:

I : adalah tahap perkenalan

$\mathrm{G}$ : adalah tahap pertumbuhan

$\mathrm{M}$ : adalah tahap kedewasaan

$\mathrm{D}$ : adalah tahap penurunan

\section{METODE PENELITIAN}

Penulis membatasi kepada hal-hal yang yang mempunyai katan langsung dan tidak langsung terhadap aspek kepariwisataan Indonesia dari sudut pandang strategi pemasaran. Begitupula meskipun disadari sepenuhnya bahwa konteks pembahasan banyak menyentuh segi-segi yang berkategorikan data-data kuantitatif, karena keterbatasan penulis dalam penyajian analisisnya lebih mengacu kepada deskriptif, kualitatif dan trend.

Menyangkut teknis pengumpulan data, penulis melakukan penghimpunan data-data yang diperoleh melalui:

1. Telaah buku-buku laporan kepariwisataan yang diterbitkan oleh pusat informasi Departemen Pariwisata Pos dan Telekomunikasi secara tahunan yang penulis terima 
sejak tahun 1991 di sekolah, meskipun data-data yang menjadi rujukan adalah datadata mulai tahun 1993.

2. Telaah majalah-majalah bulanan Media Informasi Pariwisata dari Libang Parpostel.

3. Mengacu pada studi konsentrasi pemasaran, menelaah buku-buku pemasaran yang dianggap relevan adalah tak terelakkan.

4. Observasi terbatas ke Daerah-daerah Tujuan Wisata melakukan wisata bersama murid SMIP seperti: Jakarta-Jawa-Bali Overland Tour selama 10 hari setiap perjalanan pertahun, dan Jakarta-Sumatera Utara Overland Tour selama 14 hari setiap perjalanan pertahun. Dari kedua paket wisata tersebut penulis mengikuti sejak tahun 1989.

Berdasarkan upaya-upaya menghimpun data seperti diungkap tadi, meskipun penelitian lebih mengacu pada riset kepustakaan, tetapi hasil pengamatan dari obyek - obyek wisatapun tetap menjadi pertimbangan penulis dalam memadukan penyajian data, baik secara kuantitas maupun kualitas. Kajian ini lebih mengacu kepada strategi pemasaran yang aplikatif, meskipun disadari sebagai kajian yang bersifat konseptual.

\section{HASIL DAN PEMBAHASAN}

Menurut matriks pertumbuhan pangsa pasar, pariwisata masuk ke dalam posisi kotak Cash Cow (sapi perah). Kedudukan demikian berarti ia mempunyai tingkat pertumbuhan pasar yang rendah dengan penerimaan jauh lebih besar daripada pengeluaran sehingga dapat disubsidi silang dengan kotak Question Mark (tanda tanya). Dari versi IATA terlihat pangsa pasar pariwisata Indonesia masih kecil.

PERBANDINGAN SAHAM WISMAN KE
INDONESIA VERSI IATA DAN INDONESIA
\begin{tabular}{|c|c|c|c|}
\hline Lokasi & $\mathbf{1 9 9 1}$ & $\mathbf{1 9 9 6}$ & $\mathbf{2 0 0 0}$ \\
\hline Asia Pasifik & 43,6 Juta & 61,30 Juta & 80,5 Juta \\
Indonesia Share & 2,5 Juta & 5,05 Juta & 11,0 Juta \\
& $(5,73 \%)$ & $(8,24 \%)$ & $(13,66 \%)$ \\
\hline
\end{tabular}

Sumber: Media Informasi PARPOSTEL Edisi XXIV 1996
Daerah Tujuan Wisata (DTW) jika diposisikan ke dalam matrik portfolio multifaktor, dapat diposisikan dalam kotak nomor 7 (tujuh), artinya bahwa daya tarik industri DTW adalah tinggi tetapi peta kekuatan bisnis yang dimiliki masih lemah sehingga diperlukan pembenahan-pembenahan demi merubah segi-segi kelemahan menjadi kekuatan. Hal iu menyangkut jasa-jasa pelayanan, kemampuan pengelolaan atau kemanajerialan maupun kualitas pemenuhan yang enyangkut prasana dan sarana termasuk infrastrukturnya.

Penilaian daya tarik indusri tersebut berdasarkan penilaian beberapa faktor yang melandasinya:

Keseluruhan ukuran pasar : Besar

Tingkat pertumbuhan pasar : Tinggi

Dampak lingkungan berupa stabilitas sosial dan politik : Tinggi

Sedangkan penilaian kekuatan bisnis Pariwisata Indonesia berdasarkan penilaian atas beberapa faktor mikro yang melandasi adalah sebagai berikut:

$$
\begin{array}{ll}
\text { Pangsa pasar } & : \text { Kecil } \\
\text { Jaringan Distribusi } & : \text { Lemah } \\
\text { Efektivitas Promosi } & : \text { Lemah } \\
\text { Intensitas persaingan } & \text { : Cukup }
\end{array}
$$

Menurut matrik siklus hidup produk, keadaan destinasi wisata Indonesia dilihat sebagai suatu produk, pada umumnya masih merupakan yang potensial sehingga diperlukan penelitian yang terprogram dari waktu ke waktu untuk dapat menentukan perlu atau tidaknya suatu destinasi wisata sebagai produk laik dipasarkan. Meski demikian diakui bahwa telah banyak pula destinasi wisata yang tidak diragukan lagi kualitasnya di beberapa wilayah $\mathrm{Nu}$ santara ini terutama di kota-kota besar pada tingkat provinsi.

Kedudukan pariwisata Indonesia dalam matrik siklus hidup produk atau product life cycle (PLC) berada dalam kotak nomor 14yang berarti industri pariwisata Indonesia berada dalam bentuk pertumbuhan. Sementara posisi persaingan pariwisata dalam indstri berada 
dalam posisi sedang. Penilaian siklus hidup produk didasarkan pada penilaian permintaa/ minat wisatawan untuk berkunjung ke Indonesia karena daya tarik obyek-obyek wisata yang terus meningkat. Sejalan dengan meningkatnya kualitas pariwisata Indonesia terutama berkaitan dengan akomodasi, transportasi, pelayanan, infrastruktur dan sapta pesona. Hal tersebut ditentukan oleh beberapa faktor makro yang mempengaruhi seperti perkembangan ekonomi, politik dan perdagangan kita yang semakin terbuka. Ini juga dipengaruhi oleh gaya hidup yang semakin modern, juga tujuan melakukan perjalanan yang semakin beragam. Diantaranya berkaitan dengan bisnis upaya pengembangan usaha. Sedangkan peilaian terhadap posisi bersaing pariwisata Indonesia didasarkan pada penilaian bahwa perusahaan sebenarnya cukup memuaskan untuk menjamin kelangsungan usahanya.

Menurut Analisis SWOT dipandang relevan untuk menganalisis keadaan industri pariwisata Indonesia sebagai industri jasa. Analisis swot adalah kekuatan (strength), kelemahan (weakness), peluang (opportunity), dan ancaman (threats).

\section{KEKUATAN}

Ada beberapa aspek potensial yang merupakan model pembangunan kepariwisataan Indonesia sehingga beberapa aspek tersebut dapat dianggap merupakan kekuatan yang dapat diandalkan, yaitu:

1. Pertumbuhan ekonomi yang tinggi dan makin bervarasinya kegiatan ekonomi terutama di dalam negeri sebagaimana tercermin dari berbagai keberhasilan pembangunan.

2. Stabilitas politik dan keamanan yang mantap di dalam negeri turut memberikan jaminan rasa aman bagi wisatawan manca negara yang berkunjung ke daerah destinasi wisata Indonesia.

3. Kondisi geografis yang stabil sehingga relatif aman dari terjadinya bencana ala seperti gempa bumi yang sering terjadi di Jepang dan lain-lain.

4. Keindahan serta kekayaan alam yang beraneka ragam dan sebagian besar belum tercapai, di samping iklim tropis yang sangat mendukung kegiatan pariwisata sepanjang tahun. Selain itu menjadi modal pula seni dan budaya beraneka ragam serta tersebar di seluruh pelososk tanah air.

5. Wilayah dan letak Indonesia yang strategis berada di antara Asia dan Australia yang menjadi peluang untuk pusat kepariwisataan di Asia Pasifik.

6. Data yang ada menunjukkan bahwa kepariwisataan dunia terus mengalami peningkatan, walaupun terjadi berbagai krisis yang berkepanjangan dengan dampaknya yang luas.

7. Penawaran tenaga kerja dan diklat yang semakin terprogram.

8. Biaya operasional selama berkunjung ke Indonesia, relatif termasuk murah.

9. Travel biro perjalanan.

10. Panjang lini produk.

11. Transportasi udara, darat, dan laut cukup tersedia

12. Pangsa pasar

\section{KELEMAHAN}

1. Kekuatan manajemen;

2. Reputasi pelayanan;

3. Produk masih lemah (Kualitas obyek, sarana, pelayanan, dan pengorganisasian pasar)

4. Pemasaran (strategi, sistem, bahan promosi dan sales mission)

5. Pengembangan obyek-obyek wisata dan lingkungannya sebagai Daerah Tujuan Wisata (DTW)

6. Kualitas Sumber Daya Manusia (SDM) belum memadai;

7. Koordinasi lintas sekolah atau pendidikan belum mantap;

8. Kesenjangan kewenangan pusat. 


\section{PELUANG}

1. Pertumbuhan wisatawan dunia hingga tahun 2000 sebanyak 637 orang, Asia Pasifik 114 juta dan ASEAN 43,5 juta;

2. Globalisasi ekonomi dari era Asia Pasifik (Aspas);

3. Indonesia sebagai DTW yang luas dan kaya dengan variasi keindahan alam dan keragaman budaya;

4. Stabilitas ekonomi,politik dan keamanan yang mantap dan dinamis dari waktu ke waktu termasuk kawasan ASEAN;

5. Meningkatnya pendapatan perkapita dunia;
6. Kemajuan yang dicapai dalam teknologi transportasi dan komunikasi;

7. Kemungkinan siklus perjalanan karena faktor daya tarik industri.

\section{ANCAMAN}

1. Aspek yang lebih baik dari negara-negara pesaing;

2. Kompetisi di kalangan sesama negara-negara ASEAN yang sangat ketat;

3. Kemunduran mutu lingkungan akibat kurangnya pengendalian;

4. Multi Gate AIR Policy

KUNJUNGAN WISATA MANCANEGARA KE INDONESIA DAN WISATAWAN NUSANTARA
\begin{tabular}{|l|c|c|c|}
\hline \multicolumn{1}{|c|}{ SEBAGAI TARGET MARKET } \\
\hline 1994 & Angka Awal & Kenaikan dalam pelita/tahun & Jumlah kunjungan Wisman \\
\hline VI & 4.000 .000 & $15 \%$ & 6.300 .000 \\
VII & - & $13 \%$ & 11.600 .000 \\
IX & - & $11 \%$ & - \\
$X$ & - & $9 \%$ & 30.000 .000 \\
\hline
\end{tabular}

Sumber: Analisis

\begin{tabular}{|c|c|c|c|c|c|c|}
\hline \multirow{2}{*}{ Uraian } & \multirow{2}{*}{1994} & \multicolumn{5}{|c|}{ Akhir Pelita ke } \\
\hline & & VI & VII & VIII & IX & $\mathbf{X}$ \\
\hline $\begin{array}{l}\text { Jumlah penduduk } \\
\text { Pertumbuhan } \\
\text { penduduk } \\
\text { pertahun } \\
\text { Pertumbuhan } \\
\text { GDP pertahun } \\
\text { \% penduduk } \\
\text { melakukan } \\
\text { perjalanan } \\
\text { Frekuensi } \\
\text { perjalanan } \\
\text { pertahun } \\
\text { perjalanan } \\
\text { pertahun }\end{array}$ & $\begin{array}{c}34,80 \% \\
1,12 \\
75.853 .150\end{array}$ & $\begin{array}{r}203.806 .000 \\
1,55 \% \\
6,5 \% \\
36 \% \\
1,25 \% \\
91.712 .700\end{array}$ & $\begin{array}{c}219.557 .000 \\
1,50 \\
6,25 \% \\
37,29 \% \\
1,38 \% \\
112.711 .780\end{array}$ & $\begin{array}{c}133.928 .000 \\
1,45 \\
6 \% \\
38,4 \% \\
1,50 \% \\
134.496 .000\end{array}$ & $\begin{array}{c}252.928 .000 \\
1,40 \\
5,75 \% \\
39,6 \% \\
1,63 \% \\
163.260 .000\end{array}$ & $\begin{array}{c}270.468 .000 \\
1,35 \\
5,50 \% \\
40,8 \% \\
1,75 \% \\
\\
193.114 .150\end{array}$ \\
\hline
\end{tabular}

Sumber: Hasil Analisis 
Perspektif Pertumbuhan Ekonomi secara Regional

ANGKA-ANGKA PEC DALAM TAHUN 1993

\begin{tabular}{|c|c|c|c|c|c|c|}
\hline Negara & Daerah & \begin{tabular}{|c} 
Jumlah Penduduk \\
dalam Juta Jiwa
\end{tabular} & $\begin{array}{l}\text { Pendapatan Rata- } \\
\text { rata per orang US \$ }\end{array}$ & $\begin{array}{c}\text { GDP dalam juta } \\
\text { US } \$\end{array}$ & $\begin{array}{c}\% \\
\text { Pertumbuhan GDP }\end{array}$ & $\begin{array}{c}\text { Pertumbuhan GDP/ } \\
\text { tahun dalam US \$ }\end{array}$ \\
\hline $\begin{array}{l}\text { Australia New } \\
\text { Zealand Papua } \\
\text { NG }\end{array}$ & Oceanta & $\begin{array}{l}17,5 \\
3,4 \\
4,1\end{array}$ & $\begin{array}{l}17.260 \\
12.300 \\
950\end{array}$ & $\begin{array}{l}302.250 \\
41.820 \\
3.895\end{array}$ & $\begin{array}{l}1,6 \\
0,6 \\
2,3\end{array}$ & $\begin{array}{l}4,833 \\
251 \\
90\end{array}$ \\
\hline Sub Total & & 25 & $13.910,6$ & 347.765 & 1,49 & 5.174 \\
\hline \begin{tabular}{|l} 
Brunai \\
China \\
Hongkong \\
Indonesia \\
Japan \\
Malaysia \\
Philipines \\
Singapore \\
Korea Selatan \\
Taiwan \\
Tahiland
\end{tabular} & Asia & \begin{tabular}{|l}
0,3 \\
$1.162,2$ \\
5,8 \\
184,3 \\
124,5 \\
18,6 \\
64,3 \\
2,8 \\
\\
43,7 \\
20,8 \\
58
\end{tabular} & \begin{tabular}{|l}
15.640 \\
470 \\
15.360 \\
670 \\
28.190 \\
279 \\
770 \\
15.730 \\
\\
6.790 \\
10.163 \\
1.840 \\
\end{tabular} & \begin{tabular}{|l}
4.692 \\
546.234 \\
89.088 \\
123.481 \\
3.509 .655 \\
51.984 \\
49.511 \\
44.044 \\
\\
296.723 \\
$211.390,4$ \\
106.720
\end{tabular} & \begin{tabular}{|l}
7,5 \\
7,6 \\
5,5 \\
4 \\
3,6 \\
3,2 \\
1 \\
5,3 \\
\\
8,5 \\
7,8 \\
6 \\
\end{tabular} & \begin{tabular}{|l}
351,4 \\
$41.513,8$ \\
$4.899,8$ \\
$4.939,2$ \\
$126.347,6$ \\
$1.660,6$ \\
$(495,1)$ \\
23.343 \\
\\
$25.221,5$ \\
$16.488,5$ \\
6.403 \\
\end{tabular} \\
\hline Sub total & & $1.685,3$ & $2.986,67$ & $5.033 .432,4$ & 4,56 & $229.665,1$ \\
\hline \begin{tabular}{|l|} 
Canada \\
Mexico \\
USA
\end{tabular} & & \begin{tabular}{|l|}
27,4 \\
85 \\
255,4
\end{tabular} & \begin{tabular}{|l|}
20.710 \\
3.470 \\
23.240
\end{tabular} & \begin{tabular}{|l|}
567.454 \\
294.950 \\
5.935 .496 \\
\end{tabular} & \begin{tabular}{|l|}
1.8 \\
90,20 \\
1,7
\end{tabular} & \begin{tabular}{|l|}
$10.214,2$ \\
$(589,9)$ \\
$100.934,4$
\end{tabular} \\
\hline \begin{tabular}{|l} 
Sub Total \\
\end{tabular} & & 367,8 & $18.482,6$ & 6.797 .900 & 1,63 & $110.527,7$ \\
\hline Total & Apec & $2.078,1$ & $5.680,7$ & $2.179 .097,4$ & 2,80 & $340.710,2$ \\
\hline
\end{tabular}

Sumber: BPS

PERKIRAAN PERTUMBUHAN EKONOMI

\begin{tabular}{|c|c|c|c|c|c|c|}
\hline \multirow{2}{*}{ Wilayah } & \multicolumn{3}{|c|}{ Pertumbuhan Ekonomi } & \multicolumn{3}{|c|}{ Inflasi } \\
\hline & 1994 & 1995 & 1996 & 1994 & 1995 & 1996 \\
\hline Dunia & 3,7 & 3,8 & 4,2 & 7 & - & - \\
\hline Negara Industri & 3 & 3 & 2,7 & 2,4 & 2,6 & 2,7 \\
\hline Amerika Serikat & 4,1 & 3,2 & 1,9 & 2,6 & 3,1 & 3,5 \\
\hline Jerman & 2,9 & 3,2 & 3,3 & 3,1 & 2 & 2 \\
\hline Jepang & 0,6 & 1,6 & 3,5 & 0,7 & 0,3 & 0,7 \\
\hline Perancis & 2,5 & 3,2 & 3 & 1,7 & 2 & 2 \\
\hline Inggris & 3,3 & 3,2 & 2,8 & 2,4 & 2,9 & 2,8 \\
\hline Italia & 2,5 & 3 & 3 & 4 & 5,2 & 4,2 \\
\hline Kanada & 4,5 & 4,3 & 2,6 & 0,2 & 2 & 1,9 \\
\hline Total G7 & 3,1 & 3 & 2,6 & 2,2 & 2,5 & 2,7 \\
\hline Negara Industri lain & 2,8 & 3,3 & 3,1 & - & - & - \\
\hline Unit Eropa & 2,8 & 3,2 & 3,1 & - & - & - \\
\hline Negara Berkembang & 6,3 & 5,6 & 6,1 & 4,8 & 17,5 & 8,9 \\
\hline Afrika & 2,7 & 2,7 & 5,3 & - & - & - \\
\hline Asia & 8,6 & 7,6 & 7,3 & - & - & - \\
\hline Amerika Latin & 4,6 & 2,3 & 3,7 & - & - & - \\
\hline Eropa \& Timur Tengah & $(3,8)$ & 0,4 & 3,5 & - & - & - \\
\hline Rusia & $(1,5)$ & (9) & 4,5 & - & - & - \\
\hline
\end{tabular}

Sumber: Data Olahan Sekunder

\section{KUNJUNGAN WISATA MANCANEGARA KE INDONESIA DAN WISATAWAN NUSANTARA} SEBAGAI TARGET MARKET

\begin{tabular}{|l|c|c|c|}
\hline \multicolumn{1}{|c|}{ Pelita ke } & Angka Awal & Kenaikan dalam pelita/tahun & Jumlah kunjungan Wisman \\
\hline 1994 & 4.000 .000 & $15 \%$ & 6.300 .000 \\
VI & - & $13 \%$ & 11.600 .000 \\
VII & - & $11 \%$ & - \\
IX & - & $9 \%$ & 30.000 .000 \\
X & - & $7 \%$ & 42.000 .000 \\
\hline
\end{tabular}


ASUMSI KEBUTUHAN AKOMODASI MULAI PELITA VI - X

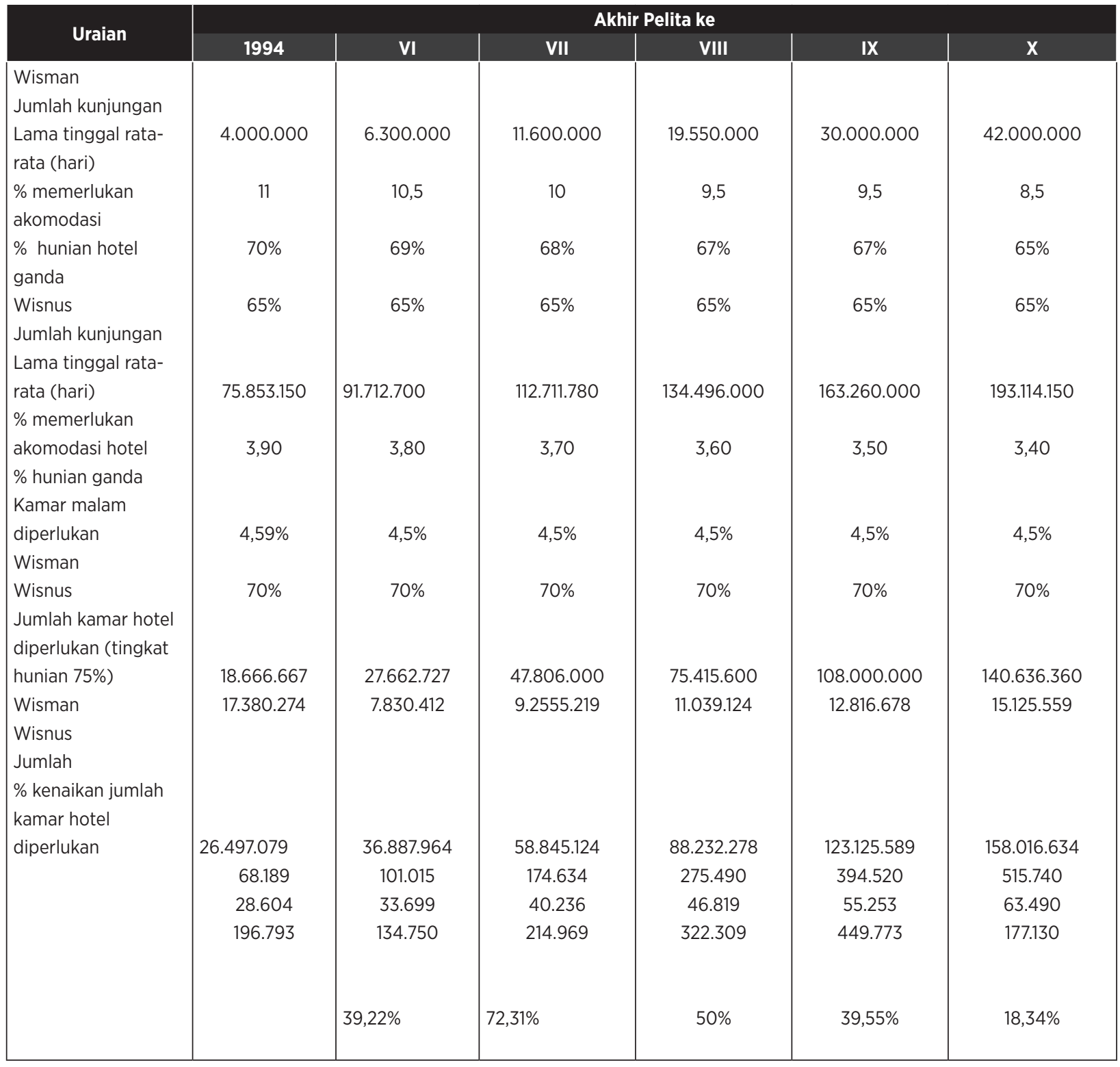

Sumber: Analisis

PENGELUARAN PERJALANAN WISATA DALAM TAHUN 1993 MENURUT BPS

\begin{tabular}{|c|c|c|c|c|c|}
\hline Jenis Pengeluaran & $\%$ & US\$ & $\%$ & US\$ & Keterangan \\
\hline $\begin{array}{l}\text { Akomodasi } \\
\text { sebelumnya } \\
\text { Makanan dan } \\
\text { minuman } \\
\text { Sovenir dan belanja } \\
\text { Transportasi lokal } \\
\text { Pesiar per-pet } \\
\text { Hiburan } \\
\text { Dikonversikan lain- } \\
\text { lain } \\
\text { Kurs Rp } 2100 \\
\text { Jumlah }\end{array}$ & $\begin{array}{l}29,59 \\
18,56 \\
26,41 \\
11,03 \\
3,34 \\
5,05 \\
6,02 \\
100 \%\end{array}$ & $\begin{array}{c}32,53 \\
20,40 \\
29,03 \\
12,12 \\
3,67 \\
5,55 \\
6,62 \\
109,92\end{array}$ & $\begin{array}{r}35,2 \\
10,80 \\
10,4 \\
19,4 \\
4,4 \\
6,2 \\
13,6 \\
100 \%\end{array}$ & $\begin{array}{l}13,60 \\
4,57 \\
4,02 \\
7,50 \\
1,70 \\
2,40 \\
5,26 \\
38,65\end{array}$ & $\begin{array}{l}\text { Pengeluaran Wisma } \\
\text { Dalam Rp sebesar rata-rata untuk seluruhnya } \\
\text { Perjalanan dalam tahun } 1991 \text { sebesar Rp } \\
81.165 \text { per orang jalanan, rupiah dalam US\$ } \\
\text { Dengan dalam tahun } 1991\end{array}$ \\
\hline
\end{tabular}

Sumber: Data dari BPS 
PROYEKSI PENDAPATAN DARI PARAWISATA PADA AKHIR PELITA VIII (2008)

\begin{tabular}{|c|c|c|c|c|c|c|}
\hline \multirow{2}{*}{$\begin{array}{l}\text { KURUN } \\
\text { WAKTU }\end{array}$} & \multicolumn{3}{|c|}{ WISMAN } & \multicolumn{3}{|c|}{ WISNU } \\
\hline & Pengeluaran & Jumlah malam & Penerimaan & Per & $\begin{array}{c}\text { Penerimaan } \\
\text { /jumlah }\end{array}$ & Perjalanan \\
\hline \multirow{9}{*}{$\begin{array}{l}1994 \\
\text { Repelita VI } \\
\text { Repelita VII } \\
\text { Repelita VIII } \\
\text { Repelita IX } \\
\text { Repelita X }\end{array}$} & US\$ & Banyaknya & Perjalanan & (Rp.1.000.000) & US\$ & \\
\hline & 109,65 & 44.000 .000 & 4.824 .600 .000 & 75.853 .150 & 99.736 & \\
\hline & & & & & & \\
\hline & 118,08 & 66.150 .000 & 7.810.992.000 & 91.712 .700 & 140.063 & 12.845 .556 \\
\hline & & & & & & \\
\hline & 113,60 & 166.000 .000 & 15.497 .600 .000 & 112.711 .780 & 198.285 & 22.349 .055 \\
\hline & 151,15 & 185.725 .000 & 28.072.333.700 & 134.496 .000 & 279.582 & 37.602 .661 \\
\hline & 171,01 & 270.000 .000 & 46.172 .700 .000 & 163.260 .000 & 394.211 & 64.358 .888 \\
\hline & 193,40 & 357.000 .000 & 9.072 .360 .000 & 193.114 .150 & 555.837 & $107.339,99$ \\
\hline
\end{tabular}

Sumber : Analisis

PROYEKSI PENDAPATAN PARIWISATA AKHIR PELITA VI (1998)

\begin{tabular}{|c|c|c|c|c|}
\hline Pengeluaran Untuk & $\begin{array}{l}\text { WISMAN \% } \\
\text { Pengeluaran }\end{array}$ & US\$ & $\begin{array}{c}\text { WISNU \% } \\
\text { Pengeluaran }\end{array}$ & Rp.1.000 \\
\hline Akomodasi & $25,30 \%$ & 2.311 .272 .533 & $39,25 \%$ & 4.521 .635 .712 \\
\hline Makanan/Minuman & $15,87 \%$ & 1.449.720.115 & $12,04 \%$ & 1.387 .320 .048 \\
\hline Pengangkutan/Transportasi lokal & $9,43 \%$ & 861.552 .418 & $21,63 \%$ & 2.492.037.864 \\
\hline Souvenir dan Belanja & $22,58 \%$ & 2.062 .882 .987 & $11,60 \%$ & 1.335.937.824 \\
\hline Atraksi, hiburan, pesiar & $7,17 \%$ & 655.342 .220 & $4,88 \%$ & 562.204 .464 \\
\hline Kesehatan/kecantikan & $5,77 \%$ & 526.667 .791 & & \\
\hline Pemandu wisata & $8,72 \%$ & 796.424 .472 & & \\
\hline Lain-lainnya & $5,15 \%$ & 470.221 .718 & $10,59 \%$ & 1.220 .327 .820 \\
\hline Jumlah & $100,00 \%$ & 9.134 .084 .254 & $100,00 \%$ & 11.519 .463 .732 \\
\hline
\end{tabular}

Sumber: BPS

PROYEKSI PENDAPATAN DARI PARIWISATA PADA AKHIR PELITA VIII (2008)

\begin{tabular}{|l|r|r|r|r|}
\multicolumn{1}{|c|}{ Uraian } & \% Pengeluaran & Wisman Us\$ & Wisnu \% Pengeluaran & Rp1.000 \\
\hline Akomodasi & $31,49 \%$ & 8.306 .603 .557 & $37,05 \%$ & 13.236 .136 .672 \\
\hline Makanan/Minuman & $19,75 \%$ & 5.210 .225 .144 & 4.061 .087 .388 \\
\hline Angktan/Transport Lokal & $11,74 \%$ & 3.096 .378 .413 & $20,42 \%$ & 7.294 .916 .234 \\
\hline Souvenir dan Belanja & $28,10 \%$ & 7.413 .903 .343 & $10,95 \%$ & 3.910 .676 .744 \\
\hline Atraksi hiburan, pesiar & $8,93 \%$ & 2.355 .268 .802 & $4,63 \%$ & 1.654 .517 .084 \\
\hline Kesehatan/Kecantikan & & & $4,32 \%$ & 1.541 .709 .101 \\
\hline Pemandu Wisata & & & $4,53 \%$ & 2.331 .364 .982 \\
\hline Lain-lain & & & 1.689 .954 .492 \\
\hline & $100,00 \%$ & 26.382 .379 .259 & $3,01 \%$ & 3.572 .795 \\
\hline Jumlah & & & $100,00 \%$ & \\
\hline
\end{tabular}

Sumber : Data Analisis Perkiraan 
Angka tahun 2008 tersebut dia atas adalah cukup mengejutkan dan pada dewasa ini dapat dinilai sebagai suatu fantastis. Angka yang lebih mengherankan akan dicapai pada akhir PJP II dalam tahun 2018 dengan pendapatan:

1. Dari wisman: US $\$ 69.072 .360 .000$,- dalam US $\$$ yang berlaku pada tahun itu.

2. Dari Wisnus : Rp. 107.339.990.000.000,- dalam rupiah yang berlaku salam tahun tersebut.

Jika angka-angka tersebut dapat terjelma pada aakhir PJP II, maka industri pariwisata akan merupakan industri terbesar dengan sumbangan devisa yang jauh melampui komoditi apapun di Indonesia. Memang Indonesia mmerlukan pengganti habisnya minyak dan sangat berkurangnya peran gas bumi dan industri pariwisata jawabannya.

Perjalanan wisnus akan berperan serta untuk menggerakkan perekonomian Indonesia. Lebih-lebih jika diperhitungkan "multiplier efect-nya”. Peristiwa beperan pula dalam pemerataan pendapatan masyarakat. Untuk mencapai sasaran tersebut maka strategi yang tepat perlu dipilih dan ditentukan secara arief dengan berbagai aspek.

Usaha mendapatkan agian yang lebih besar dari Industri Pariwisata Internasional memerlukan kebijakan atau strategi yang tepat. Karena kompetisi dalam dunia kepariwisataan saat ini menjadi lebih tajam, di mana banyak peluang yang terdapat di dalamnya benar-benar "close substitues" dan biaya relatifnya menjadi pertimbangan utama bagi keputusan para wisatawan untuk memilih karena harga pokok pariwisata bersifat elastis dan peka terhadap perubahan nilai tukar mata uang, maka strategi mendapatkan pangsa pasar wisata International yang besar perlu memperhatikan lima faktor penentu kepariwisataan, yaitu:

1. Faktor manajemen;

2. Faktor kebijakan pemerintah;

3. Faktor kemampuan investasi;

4. Faktor transfer budaya dan teknologi; dan

5. Faktor sumber daya manusia
Strategi Pemasaran Pariwisata Sebagai Industri Jasa

Pemasaran pariwisata, adalah menyangkut dua hal yaitu: pasar pariwisata dan produk wisata. Sejauh menyangkut pengertian pemasaran wisata (Salah Walah, Ph.D, 1992 dalam Pemasaran Pariwisata, p.34) adalah permintaan yang nyata atau yang masih potensial akan suatu produk wisata tertentu yang didasarkan pada suatu motivasi perjalanan. Sedangkan produk wisata menurut Medlik dan Middleton dijelaskan, dilihat dari sudut pandangan seorang wisatawan, produk wisata itu meliputi pengalaman yang paripurna sejak ia meninggalkan rumah sampai saat dia kembali lagi ke rumahnya. Produk itu meliputi gabungan dari berbagai komponen atau suatu paket wisata. Unsur-unsur utama komponen produk wisata itu terdiri atas 3 bagian:

1. Daya tarik daerah tujuan wisata, termasuk pula di dalamnya citra yang dibayangkan oeh wisatawan.

2. Fasilitas di daerah tujuan wisata yang meliputi akomodasi, usaha pengelolaan makanan, hiburan dan rekreasi.

3. Kemudahan-kemudahan pencapaian daerah tujuan wisata itu.

Strategi pemasaran untuk Industri Pariwisata tidak hanya menggunakan pemasaran eksternal namun juga pemasaran internal. Pemasaran eksternal menggambarkan aktivitas normal yang dilakukan oleh perusahaan dalam mempersiapkan, menetapkan harga, melakukan distribusi, dan mempromosikan jasa kepada pelanggan. Pemasaran Internal, menggambarkan tugas yang diemban perusahaan dalam rangka melatih dan memotivasi para karyawan agar dapat melayani para pelanggan dengan baik. Pemasaran Interaktif, menggambarkan interaksi antara pelanggan dan karyawan.

Stratei pemasaran jasa yang pokok berkaitan dengan tiga hal yang dapat dikemukakan sebagai berikut:

1. Melakukan differensiasi kompetitif;

2. Mengelola kualitas jasa;

3. Mengelola produktivitas. 


\section{Strategi Kebijakan Pemerintah dalam Bidang Kepariwisataan}

Bagi sebagian masyarkat Indonesia memandang kegiatan pariwisata sebagai yang belum bisa sepenuhnya diterima sebagai andalan penyangga pertumbuhan ekonomi nasional. Kecendrungan politik pemerintah untuk mendorong perkembangan pariwisata Nasional telah dilakukan dengan langkah-langkah konkrit, dan langkah-langkah itu makin kuat dirasakan baik melalui pengaturan (regulasi) di bidang Pariwisata maupun melalui kampanye sadar wisata sejak 1989, semuanya dirasakan makin kondusif bagi iklim usaha di sektor tersebut. Hal ini merangsang para investor untuk berpartisipasi dalam mengembangkan pariwisata nasional. Kebijakan berupa "Visit Indonesia Year" (1991) memberikaniklimusaha pariwisata yang baik. Bahkan tahun 1993 sampai dengan tahun 2000 yang diperkenalkan sebagai Dekade Kunjungan Indonesia diisi berbagai tema pariwisata yang dapat menarik bagi wisatawan mancanegara.

Aksesibilitas lain berupa Keppres No. 15 tahun 1983 telah menetapkan 26 negara dibebaskan dari keharusan memiliki visa untuk mengunjungi Indonesia. Hal ini merupakan kebijakan yang tepat untuk menarik wisatawan mancanegara. Bahkan pada tahun 1992 pemerintah menambah jumlah negara yang bebas visa menjadi 44 negara. Perlu kita amati juga UU Pariwisata No.9 tahun 1990 dan Kopmen Parpostel no. 108 tahun 1991 serta SK Dirjen Pariwisata no. 6 tahun 1992 yang mendorong pengembangan wisata Konvensi Jenis Wisata yang terakhir ini merupakan jenis wisata yang memiliki prospek yang cerah.

Untuk meraih pangsa pasar yang lebih luas dan lebih besar, usaha pemerintah dalam menciptakan stabilitas politik, bukan saja diperlukan karena berkaitan dengan harapan persepsi wisatawan baik, melainkan juga mengacu kepada keamanan dan keamanan selama tinggal di Indonesia sebagai wisatawan. Gambaran yang tercipta s. Gambaran yang tercipta selama berkunjung, akan merupakan arena publikasi di luar Indonesia sebagai berkaitan erat terhadap siklus kunjungan berikutnya. Hal ini menjadi relevan terutama jika dikaitkan dengan suatu kenyataan bahwa Indonesia masih disoroti oleh Luar Negeri mengenai: Timor-timor, demokrasi, kolusi dan korupsi, perburuhan (sistem upah) bahkan juga menyangkut isue Hak Asasi Manusia, bercitra buruk.

Isu-isu di atas langsung atau tidak langsung berpengaruh kepada lalu lintas arus wisatawan mancanegara dan kemungkinan para investor dari luar negeri merasa ragu untuk tertarik dalam ambil bagian sebagai investor menyangkut bisnis pariwisata Indonesia. Dengan berbelitnya birokrasi , masih terjadinya kolusi dan korupsi maka akan menambah besarnya jumlah pengeluaran yang termasuk dalam investasi. Sejauh ini dapat kita pahami pengaruhnya terhadap dinamika pembangunan kepariwisataan yaitu perjalanan pertumbuhannya dapat terhambat. Perkiraan demikian adalah didasarkan kepada suatu pemikiran bahwa baik para investor maupun para wisatawan akan selalu memperhitungkan setiap pengeluaran dengan manfaat yang didapatkan.

\section{Strategi Invetasi dalam Pembangunan Prasa- rana dan Sarana}

1. Dalam tahun 2018 akan diperlukan 577.230 kamar hotel dan berbagai kelas dengan penyebaran yang diasumsikan sama seperti tersebut di atas. Dengan demikian jangka waktu 25 tahun hendaknya dapat dibangun tambahan 492.039 kamar hotel atau setiap tahun hendaknya dapat dibangun 16.084 kamar hotel dengan investasi US \$ 809.346.800,- dengan nilai US \$ dalam tahun 1995.

2. Strategi investasi juga harus dilakukan untuk alat transportasi darat, laut dan udara, karena terutama wisman biasanya tidak mengunjungi satu daerah saja. Pada umumnya setiap wisman berada di suatu 
BANYAKNYA UNIT HOTEL DAN BANYAKNYA KAMAR MENURUT KELAS DALAM TAHUN 1993

\begin{tabular}{|c|c|c|c|c|c|}
\hline $\begin{array}{l}\text { Kelas Hotel Berbintang \& } \\
\text { Non Berbintang }\end{array}$ & $\begin{array}{l}\text { \% Jumlah } \\
\text { Kamar }\end{array}$ & $\begin{array}{l}\text { Jumlah } \\
\text { Kamar }\end{array}$ & $\begin{array}{l}\text { Perkiraan Investasi/ Kamar } \\
\text { Termasuk Tanah US\$ }\end{array}$ & $\begin{array}{l}\text { Investasi dalam } \\
\text { Hotel US\$ }\end{array}$ & Keterangan \\
\hline Bntang 5 & $6,70 \%$ & 11.734 & 150.000 & 1.760 .100 .000 & \multirow{7}{*}{$\begin{array}{l}\text { Menurut Nilai Tahun } \\
1995\end{array}$} \\
\hline Bintang 4 & $4,80 \%$ & 8.407 & 120.000 & 1.008 .840 .000 & \\
\hline Bintang 3 & $7,40 \%$ & 12.960 & 90.000 & 1.166 .400 .000 & \\
\hline Bintang 2 & $6,10 \%$ & 10.683 & 70.000 & 747.810 .000 & \\
\hline Bintang 1 & $5,40 \%$ & 9.457 & 50.000 & 472.850 .000 & \\
\hline Melati, dll & $69,60 \%$ & 121.895 & 30.000 & 3.656 .880 .000 & \\
\hline Jumlah/Rata-rata & $100,00 \%$ & 175.136 & 85.000 & 8.812 .880 .000 & \\
\hline
\end{tabular}

Sumber : BPS

tempat selama rata-rata 3,5 hari, kecuali Bali dimana mereka singgah untuk lebih dari 5 hari, sehingga kunjungannya setiap perjalanan akan meliputi lebih kurang 3 (tiga) daerah. Perpindahan dari suatu daerah ke daerah lainnya memerlukan angkutan setelah wisman masuk ke Indonesia melalui Bandara Internasional. Peran angkutan udara akan sangat menentukan karena Indonesia merupakan Negara Kepulauan dengan jarak tempuh yang cukup jauh dengan waktu yang terbatas yang yang tersedia oleh wisman.

3. Strategi investasi dalam prasarana, untuk transport darat dan udara, terutama bandara-bandara di daerah dan jalan raya menempati urusan prioritas yang sangat tinggi. Daerah-daerah seperi Bali, Lombok, dan kota-kota seperti Jakarta, Bandung, Yogyakarta, Solo, Ujung Pandang, Menado, Medan, Ambon, Jayapura, pasti memerlukan perluasan sarana bandara udara dan jalan untuk menampung transport lokal. Jumlah wisman yang telah menjadi sepuluh kali dari jumlah sekarang dan wisnus yang sebagian besar akan menggunakan sarana jalan raya karena lebih banyak menggunakan bus dan kendaraan bermotor lainnya, termasuk kendaraan sendiri. Betapa perlunya pelebaran dan perpanjangan jalan raya telah dirasakan setiap Lebaran dan jalan ke puncak setiap hari Sabtu dan Minggu.

\section{Strategi Fungsi Ideologi di Bidang Transfer Budaya dan Teknologi}

Pariwisata sebagai "hospality product" memerlukan perhatian dan strategi khusus terhadap dampak negatif dari kehadiran wisatawan asing ke Indonesia. Perkembangan pariwisata yang sangat berpolarisasi juga dapat menimbulkan problem-problem terhadap lingkungan terutama lingkungan sosial.

Pariwisata harus disesuaikan dengan kebutuhan dan prioritas dari masyarakat tuan rumah. Kebijakan terhadap apriwisata yang cocok hanya dapat ditentukan sesudah kebutuhan dan prioritas tersebut dirumuskan dengan tepat. Lalu jenis pariwisata yang mau ditawarkan dan diijinkan dapat dipilih dan pariwisata dapat disetujui asal ada manfaat bagi sebagian besar rakyat. Hanya saja dalam formulanya idealisme demikian tidak mudah dipraktekkan. Hinggasekarang yang telah muncul di permukaan dan dianggap persoalan adalah dampak negatif dari aktivitas kepariwisataan dengan upaya pencarian formula penyelesaiannya dilakukan sambil jalan. Jika dalam jangka panjang destinasi wisata di seluruh pelosok daerah nusantara ini mendapatkan pangsa pasar dari wisman, maka kemungkinan dampak yang diperkirakannya tidak hanya menyangkut aspek ekonomi tetapi juga persoalan sosial yang muncul tidak akan jauh berbeda dengan yang terjadi di Bali dimana masalah sosialnya sanagat rumit dianalisis. 
Pengaruh negatif dari "serbuan wisman" antara lain dapat kita amati adalah kesenjangan gaya hidup diantaranya sistem norma sosial dan kesusilaan. Dengan adanya kekhawatiran bahwa arus kunjungan wisman akan mempunyai pengaruh negatif atas keadaan sosial budaya masyarakat Indonesia sebenarnya cukup beralasan. Dapat dipastikan bahwa akan terjadi interaksi antara masyarakat Indonesia dengan wisman, dengan kehidupannya yang serba bebas dengan taraf penghidupan yang belum merata jika pengaruh "demonstration effect" dari konsumsi wisnus di daerah tujuan wisata yang sebagian besar masih erat dengan kemiskinan penduduk setempat.

Antisipasi bahwa akan terjadi perubahan dalam tata kehidupan sosial budaya itu sesungguhnya sudah dapat dipastikan. Akan tetapi apakah pengaruh ini akan bersifat positif atau negatif, sebenarnya banyak sekali tergantung dari intensitas interaksi kehidupan pribadi antara masyarakat dan wisman : semakin tinggi taraf penghidupan masyarakat penerima wisman, semakin kurangnya intensitas kontak pribadi ini dan hanya terbatas pada hubungan profesional. Hal ini terlihat pada negara-negara seperti Perancis, Amerika, dan Singapura.

\section{Strategi Pembangunan dan Pengembangan Sumber Daya Manusia}

Pariwisata merupakan industri yang padat karya dimana tenaga kerja sulit diganti dengan modal atau peralatan. Semua sektor dalam industri akomodasi di Indonesia dapat dikatakan relatif lebih padat karya dibandingkan dengan industri pengolahan. Oleh karena itu negara tertarik pada sektor pariwisata sebagai sumber penciptaan pekerjaan. Pariwisata merupakan sumber pokok dari pekerjaan pada tingkat regional dengan jenis pekerjaan bermacammacam dan berbeda antar daerah sesuai dengan situasi lingkungan destinasi wisata dan semua tenaga terampil, sangat bergantung dari sistem pembangunan dan pengembangan Manajemen Sumber Daya Manusia, baik pola pelatihan maupun aspek pendidikan.

Berdasarkan data-data tersebut di atas dapat diperkirakan akan terjadi perubahan yang mendasar dalam struktur dasar perhotelan. Dengan adanya kemajuan zaman dan makin tingginya pendapatan perorang, baik wisman dan wisnus, akaan makin tinggilah tuntutan wisatawan mengenai konsep kenyamanan. Tuntutan ini akan mengakibatkan kenaikan mutu produk dan pelayanan. Selain daripada itu investa-

Distribusi Unit Perhotelan Dan Akomodasi Lain

\begin{tabular}{|l|r|r|r|}
\hline Uraian & \multicolumn{1}{|c|}{ Berbintang } & \multicolumn{1}{|c|}{ Hotel lainnya } & \multicolumn{1}{c|}{ Akomodasi Jumlah } \\
\hline Banyaknya unit usaha & 564,00 & $7.274,00$ & $7.838,00$ \\
\hline Banyaknya kamar & $53.134,00$ & $122.003,00$ & $175.137,00$ \\
\hline Banyaknya kamar rata-rata perunit usaha & $9.421,00$ & 16,77 & 22,34 \\
\hline Banyaknya karyawan & $78.775,00$ & $60.404,00$ & $139.179,00$ \\
\hline Banyaknya karyawan/Kamar rata-rata & 1,40 & 0,50 & 0,80 \\
\hline
\end{tabular}

Sumber: BPS

Distribusi Unit Perhotelan Dan Akomodasi Lain

\begin{tabular}{|l|r|r|r|r|r|r|}
\multicolumn{1}{c|}{$\begin{array}{c}\text { Uraian tentang Tingkat } \\
\text { Pendidikan }\end{array}$} & \multicolumn{2}{c|}{ Hotel Berbintang } & \multicolumn{2}{c|}{ Akomodasi Lainnya } & \multicolumn{2}{c|}{ Jumlah } \\
\hline Universitas/Akademik & Banyaknya & \multicolumn{1}{c|}{$\%$} & \multicolumn{1}{c|}{ Banyaknya } & \multicolumn{1}{c|}{$\%$} & \multicolumn{1}{c|}{ Banyaknya } & \multicolumn{1}{c|}{$\%$} \\
\hline Kej. Perhotelan/Pariwisata & 7.937 & $10,08 \%$ & 3.233 & $5,36 \%$ & 11.160 & $12,51 \%$ \\
\hline SMU/SMIP & 17.669 & $22,43 \%$ & 3.476 & $5,76 \%$ & 21.145 & $23,71 \%$ \\
\hline SD atau Kurang & 47.070 & $59,75 \%$ & 39.262 & $65,03 \%$ & 36.332 & $40,74 \%$ \\
\hline Jumlah & 6.099 & $7,74 \%$ & 14.402 & $23,86 \%$ & 20.542 & $23,03 \%$ \\
\hline
\end{tabular}

Sumber: BPS' 
si dalam bidang perhotelan akan menjadi lebih tinggi perunit kamar, baiknya karena naiknya haga tanah maupun meningkatnya biaya pembangunan.

Untuk kepentingan tersebut mengharuskan makin majunya mutu manajemen, yang selanjutnya memerlukan peningkatan kualitas sumber daya manusia. Terampil dalam bidang profesinya dapat mendorong, memelihara dan memajukan produktivitas juga efisiensi. Sejauh ini, maka tampak erat hubungan anara kualitas SDM dengan adanya sistem pendidikan yang saling mendukung itu.

Dari angka-angka keperluan eksekutif siap pakai yang akan diperlukan oleh sektor perhotelan tampak bahwa masalah ini perlu mendapatkan perhatian yang sangat serius. Jika hal ini tidak dapat dipenuhi mau tidak mau Indonesia harus mendatangkan tenaga asing yang sangat mahal harganya. Maka tidak perlu terjadi Indonesia mengkspor TKW dengan pendapatan US \$ 500 per-orang dan harus mengimpor tenaga asing dengan biaya US \$ 17,500 per orang per bulan atau setiap orang tenaga asing harus mengekspor 35 TKW/TKI untuk mendapatkan keseimbangan antara ekspor dan impor tenaga. Tentu saja hal ini merupakan tantangan yang akan dihadapi oleh industri pariwisata dalam kurun waktu 1995-2018.

Tidak dapat disangkal lagi bahwa bahwa dalam perekonomian dunia yang semakin global dan seadanya pengakuan area perdagangan AFTA, perlu diimbangi dengan tersedianya te- naga kerja dalam kualitas yang memadai. Bahkan, perubahan kondisi perekonomian dunia tersebut, di banyak negara, digunakan sebagai dasar dilaksanakannya "curriculum educational reform" termasuk di Sekolah Menengah Kejuruan (SMK). Tidak ketinggalan SMIP sebagai sekolah Menengah Ilmu Pariwisata berubah nama menjadi SMK-kelompok pariwisata termasuk pula mengalami perubahan kurikulum. Perubahan tersebut untuk memacu ke arah perbaikan mutu lulusan termasuk menyangkut adanya suatu keharusan berlakunya. Program Sistem Ganda melalui kerjasama antara Dunia Usaha dan Dunia Industri baik berkaitan dengan "on the job training" maupun penyelenggaraan Uji Kompetensi di mana para pengujinya terdiri dari orang-orang dunia usaha dan industri dan telah dilaksanakan 1997 terutama untuk sekolah-sekolah menegah kejuruan di Jakarta.

Sasaran utama dari Pendidikan (PSG) adalah terciptanya kesesuaian apa yang dipelajari di Lembaga Pendidikan dengan apa yang terjadi di dunia usaha dan dunia industri sehingga sektor pariwisata didukung tenaga-tenaga yang sesuai dengan bidang garapannya, mulai tingkat menengah hingga yang berpendidikan diploma dan strata satu.

Akan tetapi di sisi lain, terutama berkaitan dengan pendidikan tinggi, kita melihat beberapa kekurangan dalam pendidikan tinggi kepariwisataan kita. Sistem Kredit Semester (SKS) yang diterapkan di semua perguruan tinggi kita, baik akademi maupun universi-

Perkiraan Distribusi Jumlah Kamar Hotel dan Akomodasi Lainnya

(1993-2018)

\begin{tabular}{|l|r|r|r|}
\multicolumn{1}{|c|}{ Uraian } & Hotel Berbintang & Akomodasi Lainnya & Jumlah \\
\hline Perkiraan jumlah kamar pada tahun 2018 & 172.310 & 383.527 & 555.837 \\
\hline Yang ada pada tahun 1993 & 53.241 & 121.896 & 175.137 \\
\hline Perkiraan tambahan dalam 25 tahun & 119.069 & 261.631 & 380.700 \\
\hline Diperlukan tambahan pertahun & 4.763 & 10.467 & 15.228 \\
\hline Kebutuhan karyawan perkamar (lebih tinggi dari angka BPS) & $1,97 \%$ & $1 \%$ & $1,17 \%$ \\
\hline Keperluan tambahan karyawan & 8.335 & 9.419 & 17.754 \\
\hline \% eksekutif inti yang diperlukan & $7,50 \%$ & $2 \%$ & $458 \%$ \\
\hline Tambahan pertahun eksekutif inti yang diperlukan & 625 & 188 & 813 \\
\hline
\end{tabular}


tas, tidak jarang membuat para mahasiswanya hanya bertanggungjawab kepada target SKS yang harus dicapai untuk lulus, bukan kepada disiplin ilmu yang dipelajari. Padahal, dalam dunia pariwisata, seperti juga bidang-bidang lainnya, tanggung jawab keilmuan itulah akan melahirkan sikap profesional, berdedikasi, dan wawasan yang memadai. Di samping itu, sistem pendidikan yang dikemas sedemikian rupa dengan kurikulum masing-masing mata pelajaran yang lebih terintegrasi satu sama lain dan suasana pendidikan yang memungkinkan para guru untuk lebih berintegrasi dan berkomunikasi, mendorong munculnya situasi yang lebih mengutamakan kualitas. Dengan kata lain, sistem yang ada di sekolah ini dengan sendirinya menciptakan kondisi di mana para murid terkontrol dan mudah diarahkan menjadi enagatenaga terampil/berkualitas di bidangnya.

Secara umum, sistem pendidikan kepariwisataan mempunyai tujuan seperti berikut:

1. Pengembangan seluruh kemampuan serta kepribadian manusia;

2. Mobilitas manusia dari satu pengalaman pendidikan ke yang lain;

3. Diversifikasi dalam pendidikan dan proses belajar;

4. Demokratisasi dalam pendidikan dan proses belajar;

5. Mobilitas sumber-sumber masyarakat yang bisa dimanfaatkan;

6. Pertumbuhan kegairahan penelitian;

Semua pihak di wilayah wisata sebenarnya harus menerima beberapa pendidikan atau latihan walaupun pendidikan tersebut hanya dalam bentuk keterangan atau informasi saja. Pada umumnya, bagian dari masyarakat wilayah wisata yang harus menerima pendidikan/ latihan adalah:

1. Tenaga yang memberi pelayanan pribadi, yang sering dilihat oleh wisman dan mempunyai banyak kesempatan untuk berbicara dengan wisatawan mancanegara seperti pegawai hotel, motel, penginapan, rumah makan, dan pompa bensis; pegawai negeri di kantor pemerintahan; dan yang bekerja di kebun hiburan dan bisnis pariwisata yang memberi informasi kepariwisataan;

2. Tenaga yang menawarkan pelayanan khusus baik untuk masyarakat wilayah wisata maupun untuk para wisman. Tenaga ini termasuk polisi, tukang listrik, pembuang sampah, para penjaga, tenaga kesehatan, pegawai bank, dan pemilik dan pegawai toko-toko.

3. Masyarakat wilayah wisata harus diberitahu tentang perkembangan wisata supaya suasana kesopanan dan keramah-tamahan bertahan dan supaya para wisman merasa kerasan (welcome). Semakin besar rasa senang di tempat wisata semakin lama para wisman akan tinggal di sana dan semakin cepat mereka akan datang lagi.

4. Tenaga yang bekerja di Kantor Penerang Pariwisata (Tourist Information Counters)

\section{KESIMPULAN DAN SARAN Kesimpulan}

Berdasarkan kepada uraian-uraian yang telah dikemukakan pada bab-bab sebelumnya, maka penulis dapat memberikan kesimpulankesimpulan sederhana sebagai berikut:

1. Ditinjau dari sudut pandang bisnis, bahwa pariwisata termasuk sektor industri jasa yang dalam segi kemanajerialannya tidak dapat terlepas dari prinsip-prinsip manajemen sesuai dinamikanya yang semakin modern baik secara konsepsional maupun operasional sejalan pula dengan semakin berkembangnya aktivitas kepariwisataan secara kualitas dan kuantitas.

2. Mengingat trend manusia modern untuk mengadakan perjalanan baik jarak waktu singkat maupun lama, baik kepentingan bisnis ataupun nonbisnis, maka adanya peluang pasar pariwisata menjadi tidak terelakkan mengingat gaung era pasar bebas semakin menjadi suatu realitas kehidupan.

3. Keberhasilan Indonesia dalam menyerap derasnya arus wisatawan manca negara (wisman) dan memobilisasi wisatawan 
nusantara (wisnus) dapat tercapai, dengan menggunakan strategi-strategi pengembangan dan pengelolaan produk-produk wisata termasuk aspek pemasarannya yang senantiasa dikembangkan secara konsepsi, teoritis, maupun formulasi.

4. Secara konteks perekonomian Indonesia termasuk negara yang masih perlu dipacu pertumbuhan ekonominya, mengingat masih sulit untuk menghindari import maka peranan devisa negara sangat strategis dalam melicinan arus impor terutama berkaitan dengan teknologi yang berfungsi untuk produktif. Dalam hubungan demikian pariwisata diharapkan mendatangkan devisa atau sebagai sumber devisa negara.

5. Keberhasilan sektor pariwisata dalam menerobos pasar ASEAN dan Internasional tidak hanya memerlukan konsep strategis pemasaran yang tepat, melainkan juga memerlukan perbaikan dan peningkatan daya saing baik produk maupun kemampuan Sumber Daya Manusia (SDM) sekaligus komitmen kinerja yang tinggi dari tingkat pusat hingga ke daerah-daerah.

\section{Saran}

Berkaitan dengan kesimpulan - kesimpulan yang telah dikemukakan, maka untuk melengkapi langkah-langkah operasional dalam kerangka semakin solidnya konsep-konsep yang ditawarkan dapat memberikan saran-saran sebagai berikut:

1. Karena sektor pariwisata Indonesia sangat berkaitan dengan manajemen kebijakan pemerintah, maka secara teknis operasional sebaiknya mengacu kepada dua sasaran yaitu:

2. Sasaran ke dalam, pemerintah dan jajarannya harus mempunyai persepsi yang sama tentang pariwisata menyangkut konsep, sistem manajemen maupun sasaran yang akan dicapai dari tingkat pusat hingga operasional lapangan (Daerah-daerah tujuan wisata), dan peningkatan keterlibatan pihak swasta yang semakin terprogram.
3. Sasaran ke luar, kebijaksanaan perpolitikan Indonesia dari pemerintah selain menunjukkan image yang baik di mata luar negeri juga melakukan perbaikan citra perpolitikan dalam negeri di mata luar negeri termasuk pemeliharaan stabilitas politik karena pariwisata tidak terlepas dari terpenuhinya kebutuhan rasa aman dan nyaman. Begitu pula melakukan penyederhanaan proses untuk memperoleh fasilitasfasilitas (dokumen-dokumen) yang diperlukan oleh warga asing yang akan masuk ke Indonesia, tanpa harus mengabaikan sikap kewaspadaan nasional.

4. Terbukanya peluang pasar pariwisata Indonesia di dalam dan luar negeri maka pemanfaatan peluang demikian, menuntut tersedia produk-produk dan sistem pelayanan wisata yang standar kualitasnya terjaga dan teruji dengan melakukan penelitian, penyelesaian, pengelolaan dan pengembangan produk wisata. Termasuk pembangunan, perbaikan dan pemeliharaan infrastruktur seperti fasilitas jalan raya dan alat transportasi, juga tersedianya akomodasi atau perhotelan yang memenuhi standar kualifikasi yang dapat diterima secara internasional.

5. Untuk peningkatan kualitas pelayanan dalam kerangka kepuasan penggunaan jasa, maka pemerintah perlu melakukan perbaikan terus menerus dalam kurikulum pendidikan sehingga menunjang terciptanya kualitas sumber daya yang dapat menerapkan prinsip-prinsip pemasaran dan kemampuan manajemen dengan berorientasi kepada teori dan praktek. Begitupula usaha membangkitkan kesadaran terhadap masyarakat, yaitu: Sadar wisata.

6. Hubungan baik antara negara menyangkut kerja sama ekonomi dan perdagangan, sejauh terkait dengan kepariwisataan harus diikuti dengan upaya mempermudah prosedur birokrasi hingga diperolehnya ijin masuk investor ke Indonesia tanpa harus mengabaikan aspek peraturan nasional 
yang keabsahannya dapat diterima atau difahami demi meningkatnya gairah berinvestasi, mengingat banyaknya kandungan kelengkapan daei pariwisata banyak tidak murah harganya.

7. Dalam kerangka menerobos pasar pariwisata secara global, standarisasi produk dan pelayanan wisata harus mengacu kepada standar yang diterima secara global tanpa harus mengorbankan paradigma lokal. Untuk mendukung langkah demikian diperlukan kemampuan berfikir global dan berbuat lokal atau jika mungkin kemampuan berfikir global dan berbuat global. Sebagai contoh adalah upaya menciptakan kemampuan SDM yang standar kinerjanya mampu bersaing dengan tenaga asing. Untuk itu differensiasi produk-produk wisata melalui penelitan dan selektifitas produk, atau bila memungkinkan melakukan inovasi sebagai upaya pengembangan produk wisata.

\section{DAFTAR PUSTAKA}

Bagir, H.1995.Era Baru Manajemen Etis.Mizan. Bandung

Cahyono, T,B.1995.Revolusi Pemasaran.Badan Penerbit IPWI.Jakarta

Cahyono, T,B.1995.Pemasaran Strategi (Pendekatan Keunggulan Bersaing).Badan Penerbit IPWI.Jakarta

Departemen Pariwisata Pos dan Telekomunikasi.1993.Pariwisata Indonesia (Laporan Tahunan). Proyek Pengembangan Usaha Sarana Pariwisata. Jakarta

Departemen Pariwisata Pos dsan Telekomunikasi.1994.Informasi Operasional Hotel. Proyek Pengembangan Usaha Sarana Pariwisata.Jakarta

Departemen Pariwisata Pos dsan Telekomunikasi.1995.Informasi Operasional Hotel. Proyek Pengembangan Usaha Sarana Pariwisata.Jakarta

James, J, Spilane, S,J.1994.Pariwisata Indonesia: Siasat Ekonomi dan Rekayasa Kebudayaan. Kanisius. Jakarta
Kartajaya.1996.Marketing Plus 2000 Siasat Memenangkan Persaingan Global. PT Gramedia Pustaka Utama.Jakarta

Naisbiti, J, Aburdene, P.1990.Megatrends 2000. Binarupa Aksara. Jakarta

Naisbiti, J.1994. Global Paradox. Binarupa Aksara. Jakarta

Naisbiti, J.1996.Mega Trends Asia. PT. Gramedia Pustaka Utama. Jakarta

1996. Edisi XXIV, Media Informasi Parpostel. Jakarta

1996. Edisi XXIV, Media Informasi Parpostel. Jakarta

1996. Edisi XXIV, Media Informasi Parpostel. Jakarta

Porter, E,M.1994.Keunggulan Bersaing (Menciptakan dan Mempertahankan Kinerja Unggul). Binarupa Aksara.Jakarta

Kotler, P.1994. Manajemen Pemasaran (Analisis, Perencanaan, Implementasi dan Pengendalian). Edisi Indonesia, Salemba Empat. Jakarta

Porter, E,M.1996.Strategi Bersaing (Teknik Menganalisis Industri dan Pesaing).Erlangga.Jakarta

New Jersey

Kotler, P, Paul, N, Bloom.1987.Teknik dan Strategi : Memasarkan Jasa profesional. CV Intermedia. Jakarta

Wahab, S.1992. Pemasaran Pariwisata.Edisi Indonesia, PT. Pradnya Paramita.Jakarta

Swasono Y.1995.Seminar Sehari (Penduduk, Peluang Usaha, dan Globalisasi.Jakarta

Tjiptono, F.1995.Strategi Pemasaran.Andi Offset.Yogyakarta

Wardiman, Djojonegoro.1993.Seminar Nasional (Strategi Pendidikan Kejuruan dalam Pengembangan Dunia Usaha Kecil dan Menengah yang Kompetitif. Jakarta

Warren,J, Keagan.1996.Manajemen Pemasaran Global.Edisi Bahasa Indonesia Jilid 1, Prenhallindo.Jakarta

Wijaya, F.1996.Pemasaran Prinsip dan Kasus. BPFE. Yogyakarta 